\title{
Micro-fungi and mycotoxins in poultry dust
}

\section{Microfungos e micotoxinas em poeira de confinamento}

\author{
Pius A Okiki ${ }^{[a]}$, Anthony Ogbimi $\mathrm{O}^{[\mathrm{b}]}$
}

\begin{abstract}
Dust in poultry confinement facilities were investigated for their fungi and mycotoxins contents. Concentrations of microfungi in the air of poultry confinement facilities were determined using air samplers, and fungal isolation from air by plate exposure. Settled dusts were investigated for their fungal load, types of fungi present and mycotoxins present. Microfungal load in settled dust and air of poultry confinements were found to be $3.5-42 \times 10^{6} \mathrm{cfu} / \mathrm{g}$ and $5-119 \times 10^{5} \mathrm{cfu} /$ $\mathrm{m}^{3}$ respectively. Fungi isolated from poultry confinements were: Aspergillus niger, Aspergillus flavus, Aspergillus fumigatus, Aspergillus parasiticus, Aspergillus ochraceus Penicillium notatum, Mucor racemosus, Penicillium oxalicum, Trichoderma viride, Stachybotrys atra, Fusarium oxysporum, Candida albicans, Cryptococus neoformans and Saccharomyces cerevisae. Mycotoxins concentrations obtained from the analyses of sieved poultry dust were $21.32 \pm 2.35 \mathrm{ppb}$ of aflatoxins, $11.26 \pm 1.78 \mathrm{ppb}$ of ochratoxins and $4.10 \pm 0.13 \mathrm{ppb}$ of fumonisins. Aflatoxin concentrations and fungal loads in settled dust showed positive correlation with duration of dust deposition, but the former produced stronger association than the latter $(r=+0.991, P<0.001$ and $r=+0.957, P<0.02$ respectively). Results obtained in this study indicate that poultry dust is rich in mirofungi and mycotoxins which could be of occupational health importance.
\end{abstract}

Keywords: Air sampling. Mould. Mycotoxins. Occupational health. Poultry dust.

\section{Resumo}

Poeiras presentes em ambientes de confinamentos de aves foram avaliadas para verificação da ocorrência de fungos e micotoxinas. Para tal, foram utilizados amostradores de ar e realizado o isolamento de fungos do ar pela exposição de placas. As poeiras foram investigadas quanto à quantidade e tipos de fungo e micotoxinas. A carda de microfungos quantificada foi de 3,5-42 × 106 ufc/g, 5-119 X105 UFC/m³ , respectivamente, estando presentes as seguintes espécies: Aspergillus niger, Aspergillus flavus, Aspergillus fumigatus, Aspergillus parasiticus, Aspergillus ochraceus, Penicillium notatum, Racemosus mucor, Oxalicum penicillium, Trichoderma viride, Atra stachybotrys, Fusarium oxysporum, Albicans candida, e Cryptococus neoformans e Saccharomyces cerevisiae. As concentrações de micotoxinas obtidas nas análises de pó peneirado foram de 21,32 2,35 ppb de aflatoxinas, 11,26 1,78 ppb de ocratoxinas 0,13 e 4,10 ppb de fumonisinas. As concentrações de aflatoxina de fungos e cargas em pó apresentaram correlação positiva com o tempo de deposição de pó, mas o primeiro produzindo associação mais forte do que o último ( $r=0,991, p<0,001 \mathrm{er}=0,957, p<0,02$, respectivamente). Os resultados obtidos neste estudo indicam que a poeira presente em ambientes de confinamento de aves de capoeira érica em microfungos e micotoxinas que possam ser de importância para a saúde ocupacional.

Palavras-chave: Avaliação da qualidade do ar. Mofo. Micotoxinas. Saúde ocupacional. Poeira de confinamento.
${ }^{[a]}$ Department of Microbiology, University of Benin, Benin-city - Nigeria, e-mail: piusokiki@yahoo.com

${ }^{[b]}$ Department of Microbiology, University of Benin, Benin-city - Nigeria.
Received: 08/06/2010

Recebido: 06/08/2010

Approved: $12 / 29 / 2011$

Aprovado: 29/12/2011 


\section{Introduction}

Fungi affect human and animal well beings in variety of ways, such as diseases of essential crop plants, decay of stored foods with possible concomitant production of mycotoxins, superficial and systemic infections of both human and animal tissues. The spores of a large number of important fungi are less than $5 \mu \mathrm{m}$-aerodynamic diameters and are therefore able to enter the lungs. They may also contain significant amount of mycotoxis. Diseases associated with inhalation of fungal spores include toxic pneumonitis, hypersensitivity pneumonitis, tremors, chronic fatigue syndrome, kidney failure and cancer (1). With exception of mushroom toxins, approximately 350-400 fungal metabolites are considered to be toxic (1). The most important mycotoxins in agriculture are the aflatoxins, ochratoxins, the 12,13-epoxytrichothecenes and the fumonisins; which are produced by species of fungi belonging to the genera Aspergillus, Penicillum and Fusarium. Other toxigenic fungi include Stachybotris atra and the species of Alternaria, Paecilomyces, Trichoderma and Trichothecium. All of these fungi occur commonly in soil, agriculture products, grain dust and house dust (2).

Species of fungi in which mycotoxins have been reported in the spores include Alternaria alternata (3), Aspergillus fumigatus (4); Aspergillus flavus and Aspergillus parasiticus (5), Fusarium graminearum (6); Fusarium sporotrichioides (6) and Stachybotris atra (1). It was suggested that workers and others who handle infected grains may be at risk of exposure by inhalation. Since majority of mycotoxins are non-volatile, mycotoxin exposure by inhalation is most likely to occur via inhalation of spores. (1).

Mycotoxins are a diverse group of fungal secondary metabolites, which are generally harmful to animals and humans. Mycotoxicoses are diseases that result from consumption of or exposure to mycotoxins (7).

A mycotoxin contaminated diet may lead to substantial economic loses in livestock due to feed refusal, poor feed conversion, diminished body weight gain, immune-suppression, interference with reproductive capabilities and residues in animal products (8). Harmful effects of various mycotoxins to animals and humans have been well documented by Jacobsen et al. (7).

The mycotoxins producing fungi may contaminate agricultural products in the field (pre-harvest), during storage (post-harvest) or during processing (8).
Mycotoxins are currently considered as a serious threat to the poultry farming in terms of diseases leading to synergistic interactions with other infections. Mycotoxins that have been associated with poultry feeds/ingredients contamination include: aflatoxins, ochratoxins, trichothecenes, citrinin, streigmatocystin and diacetoxysarphenol (9). T-2 toxins have several effects on poultry, causing oral lessons and immuno-deppression. The fumonisins can affect the growth performances of broiler at doses as low as $75 \mathrm{ppm}$ (10). Stoev et al. (11) reported a significant decrease in body mass and relative weight of lymphoid organs of broiler chicken fed a mouldy diet containing Ochratoxin and penicillic acid. They equally observe pathomorphological changes such as cloudy swelling and granular degeneration in the epithelium and mononuclear cell infiltration and activation of capillary endothelium in the kidney and liver; degenerative changes and depletion of lymphoid organs (bursa of Fabricius, thymus and spleen).

Exposure to microfungi-laden dust in poultry housings can result in a variety of disease conditions. Mycopathy is a collective term used for diseases caused by fungi, either living or dead or their metabolic products (toxins, allergens or enzymes). This complex term comprises disease manifestations e.g. mycosis, mycotic colonisation, myco-allergosis, mycetism and mycotoxicoses (9).

\section{Material and methods}

\section{Concentration of fungi in air}

This was carried out with the aid of personal samplers as described by Hendric et al. (12). Air was drawn through isopore filters (ATTD $0.8 \mu \mathrm{m}$, Millipore, Cambridge Mass, USA) with the aid of a pump at a flow rate of $5 \mathrm{~L} / \mathrm{mm}$ for 30 minutes. The filters were rinsed in sterile water. The aliquot $(0.1 \mathrm{ml})$ was plated on nutrient agar for bacterial load on one hand and potato dextrose agar from fungal load on the other hand.

\section{Isolation of microfungi from air in poultry confinements}

Sterile plates of potato dextrose agar, PDA and subouraud dextrose agar, SDA (Oxoid, England) incorporated with penicillin and streptomycin were carefully 
exposed to air for 2 minutes in poultry confinements. Following exposure, the lids were replaced taken to the laboratory and incubated for 3 - 5 days at room temperature $\left(28^{ \pm 2}{ }^{\circ} \mathrm{C}\right)$. Discrete colonies were subcultured, fungi isolated and characterized based on their cultural and morphological appearances.

Isolation of fungi from settled

dusts and poultry litter

The $10^{4}$ and $10^{3}$ dilutions of poultry dust and litters were found best for fungal growth. One millilitre of each of the two dilutions was mixed separately with $9 \mathrm{ml}$ of PDA and SDA (Oxoid, England) enriched with penicillin $(250$ units $/ \mathrm{mL})$ and streptomycin $(0.05 \mathrm{~g} / \mathrm{mL})$ in sterile plates. The plates in duplicates were incubated at $28 \pm 2^{\circ} \mathrm{C}$ for $3-5$ days. The fungal colonies that developed were counted and sub-cultured to obtain pure cultures, which were identified according to Barnet and Hunter (13) and Domsch and Gams (14).

\section{Mycotoxins assay in poultry dusts}

Investigations were carried out for the presence of aflatoxin, ochratoxins and fumonisins in settled poultry dusts, by methods described by AOAC (15).

Aflatoxin and ochratoxin tests by enzyme linked immunosorbent assay (ELISA): The concentration of aflatoxin in compounded feed samples were determined by a direct competitive enzyme-linked immunosorbent assay (ELISA), using the Agra Quant ${ }^{\circledR}$ Total Aflatoxin Assay 4/40 Kits (Romer Laboratory Inc., Singapore). Twenty grammes of ground feed samples were added to $100 \mathrm{~mL}$ of 70\% methanol for extraction of aflatoxin and filtered. The filtrate and enzyme conjugated aflatoxin were mixed and added to antibody coated microwell. Aflatoxin in samples and standards were allowed to compete separately with enzyme conjugated aflatoxin for antibody binding sites. After a step of 5 washes, an enzyme substrate was added and blue colour developed. This was followed by addition of stop solution. Absorbances were read at $460 \mathrm{~nm}$ by a computerized microplate reader and total aflatoxin expressed in parts per billion (ppb). The concentration of ochratoxin in each feed sample was determined using AgraQuant ${ }^{\circledR}$ Ochratoxin Assay Kits (Romer Laboratory Inc., Singapore). The technique is also a direct competitive ELISA. The procedure was same as described for aflatoxin assay.
Aflatoxin and fumonisins assay by high-performance liquid chromatography: High-performance liquid chromatography, HPLC, was used for determination of the concentrations of aflatoxins $\left(B_{1}, B_{2}, G_{1}, G_{2}\right)$ and total fumonisins in poultry dust. Methanol-water extraction of the sieved poultry dust was analysed in the HPLC system coupled with UV, a diode array detector.

\section{Results}

Mycotoxins concentrations obtained from the analyses of sieved poultry dust were $21.32 \pm 2.35 \mathrm{ppb}$ of aflatoxins, $11.26 \pm 1.78 \mathrm{ppb}$ of ochratoxins and $4.10 \pm 0.13 \mathrm{ppb}$ of fumonisins (Table 1 ). In a study carried out over a period of one year, in a deep litter poultry pen, aflatoxin concentrations and fungal loads in settled dust on the walls of the pens showed positive correlation with duration of dust deposition, but the former produced stronger association than the latter $(\mathrm{r}=+0.991, \mathrm{P}<0.001$ and $\mathrm{r}=+0.957$, $\mathrm{P}<0.02$ respectively; Graphic 1 ).

Microfungal load in settled dust and air of poultry confinements were found to be $3.5-42 \times 10^{6} \mathrm{cfu} / \mathrm{g}$ and $5-119 \times 10^{5} \mathrm{cfu} / \mathrm{m}^{3}$ respectively. Fungi isolated from poultry confinements were: Aspergillus niger, Aspergillus flavus, Aspergillus fumigatus, Aspergillus parasiticus, Aspergillus ochraceus, Penicillium notatum,

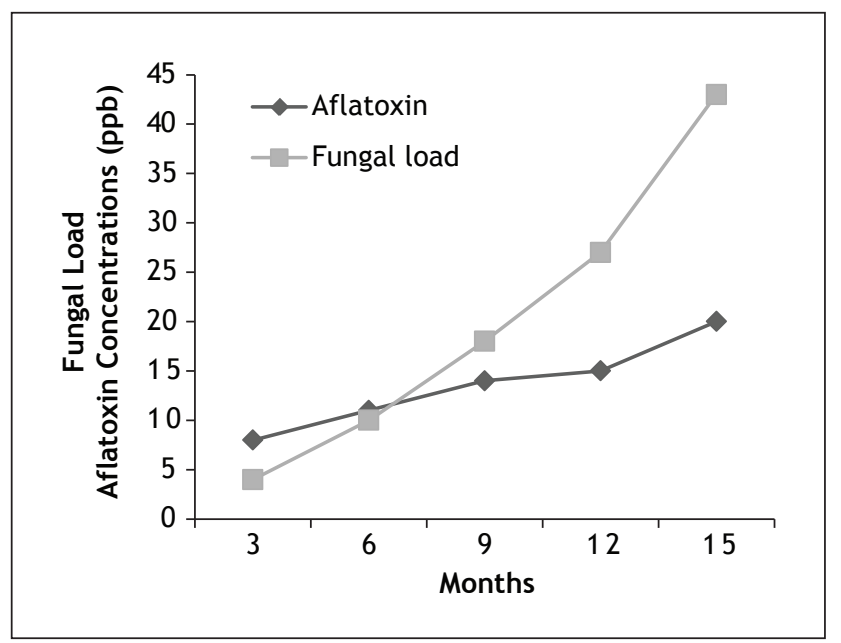

Graphic 1 - Variation of aflatoxin concentration and fungal load in poultry dust over a period of 15 months in a poultry building (Aflatoxin: $r=+0.990, p=0.001$; Fungal load: $r=+0.983, P=0.003$; Fungi/Aflatoxin: $F=27.245, r=+0.949, p=0.014$ )

Source: Research data. 
Mucor racemosus, Penicillium oxalicum, Trichoderma viride, Stachybotrys atra, Fusarium oxysporum, Candida albicans, Cryptococus neoformans and Saccharomyces cerevisae (Table 2). Mycological investigation of poultry litter over a period of 10 weeks, from the day fresh wood shavings were introduced, showed a positive correlation for fungal load $(r=+0.972, \mathrm{P}=0.006)$ as well as variation in fungi species with age of litter (Table 3 ).

Table 1 - Mycotoxins in poultry dust

\begin{tabular}{|c|c|c|c|c|}
\hline $\begin{array}{l}\text { Myco- } \\
\text { toxins } \\
\text { (ppb) }\end{array}$ & $\begin{array}{l}\text { Confine- } \\
\text { ments } \\
\text { average }\end{array}$ & $\begin{array}{l}\text { Rearing } \\
\text { house } \\
\text { of birds < } \\
8 \text { wks. }\end{array}$ & $\begin{array}{l}\text { Deep } \\
\text { litter } \\
\text { housing } \\
\text { adult } \\
\text { birds }\end{array}$ & $\begin{array}{l}\text { Battery } \\
\text { cage } \\
\text { system }\end{array}$ \\
\hline *Aflatoxin & $10.99 \pm$ & $16.30 \pm$ & $11.80 \pm$ & $12.72 \pm$ \\
\hline B1 & $\begin{array}{l}0.35(9.34- \\
15.31)\end{array}$ & 1.29 & 1.27 & 2.14 \\
\hline $\begin{array}{l}\text { *Aflatoxin } \\
\text { B2 }\end{array}$ & $\begin{array}{l}4.13 \pm 0.22 \\
(2.98-5.27)\end{array}$ & $4.57 \pm 0.99$ & $3.69 \pm 0.51$ & $4.02 \pm 0.64$ \\
\hline $\begin{array}{l}\text { *Aflatoxin } \\
\text { G1 }\end{array}$ & $\begin{array}{l}5.52 \pm 1.92 \\
(2.18-9.24)\end{array}$ & $7.20 \pm 1.88$ & $2.82 \pm 0.88$ & $4.59 \pm 1.60$ \\
\hline **Total & 20.64 & $28.07 \pm$ & $18.31 \pm$ & $21.33 \pm$ \\
\hline Aflatoxin & $\begin{array}{l} \pm 1.42 \\
(14.64- \\
28.41)\end{array}$ & 0.49 & 2.52 & 2.35 \\
\hline $\begin{array}{l}\text { *Fumoni- } \\
\text { sins }\end{array}$ & $\begin{array}{l}2.83 \pm 0.92 \\
(2.18-6.75)\end{array}$ & $6.48 \pm 0.38$ & $3.29 \pm 1.93$ & $4.10 \pm 0.13$ \\
\hline $\begin{array}{l}\text { **Ochrato- } \\
\text { xins }\end{array}$ & $\begin{array}{l}12.71 \pm \\
0.75(5.21- \\
17.73)\end{array}$ & $\begin{array}{l}15.64 \pm \\
2.12\end{array}$ & $8.16 \pm 1.42$ & $\begin{array}{l}11.26 \pm \\
0.13\end{array}$ \\
\hline
\end{tabular}

Values are mean \pm SD; Range in bracket; Aflatoxin $\mathrm{G} 2$ was not detected;

* Analyzed by HPLC

${ }^{* *}$ Analyzed by ELISA

Source: Research data.

Table 2 - Frequency of isolation of fungi in poultry confinements

\begin{tabular}{lccc} 
& & & (continues) \\
\hline \multicolumn{1}{c}{ Fungi } & Litter (25) & $\begin{array}{c}\text { Settled dust } \\
\mathbf{( 5 0 )}\end{array}$ & $\begin{array}{c}\text { Airborne } \\
\mathbf{( 5 0 )}\end{array}$ \\
\hline $\begin{array}{l}\text { Aspergillus } \\
\text { flavus } \\
\begin{array}{l}\text { Aspergillus } \\
\text { niger }\end{array}\end{array}$ & 72 & 68 & 52 \\
$\begin{array}{l}\text { Aspergillus } \\
\text { fumigatus } \\
\text { Aspergillus } \\
\text { ochraceus }\end{array}$ & 60 & 56 & 44 \\
\hline
\end{tabular}

Table 2 - Frequency of isolation of fungi in poultry confinements

(conclusion)

\begin{tabular}{|c|c|c|c|}
\hline \multicolumn{4}{|c|}{ Frequency of occurrence (\%) } \\
\hline Fungi & Litter (25) & $\begin{array}{l}\text { Settled dust } \\
(50)\end{array}$ & $\begin{array}{c}\text { Airborne } \\
\text { (50) }\end{array}$ \\
\hline $\begin{array}{l}\text { Penicillium } \\
\text { notatum }\end{array}$ & 42 & 38 & 16 \\
\hline $\begin{array}{l}\text { Penicillium } \\
\text { oxalicium }\end{array}$ & 28 & 22 & 6 \\
\hline $\begin{array}{l}\text { Mucor rac- } \\
\text { emosus }\end{array}$ & 78 & 72 & 66 \\
\hline $\begin{array}{l}\text { Alternaria } \\
\text { alternata }\end{array}$ & 12 & 4 & - \\
\hline $\begin{array}{l}\text { Fusarium } \\
\text { oxysporum }\end{array}$ & 10 & 6 & - \\
\hline $\begin{array}{l}\text { Trichoderma } \\
\text { viridis }\end{array}$ & 16 & 10 & 6 \\
\hline $\begin{array}{l}\text { Stachybotrys } \\
\text { atra }\end{array}$ & 8 & 4 & - \\
\hline $\begin{array}{l}\text { Saccharomy- } \\
\text { ces cerevisae }\end{array}$ & 44 & 32 & 24 \\
\hline $\begin{array}{l}\text { Cryptococcus } \\
\text { neoformans }\end{array}$ & 26 & 8 & - \\
\hline $\begin{array}{l}\text { Candida } \\
\text { albican }\end{array}$ & 56 & 46 & 16 \\
\hline
\end{tabular}

Sample size in bracket

Source: Research data.

Table 3 - Microfungi in poultry litter monitored over a period of 10 weeks in a deep litter pen

\begin{tabular}{lcl}
\hline Specimen & $\begin{array}{l}\text { Fungal load }\left(\times 10^{5}\right. \\
\text { cfu/g) }\end{array}$ & Isolated fungi \\
\hline $\begin{array}{l}\text { Fresh wood } \\
\text { shaving } \\
1 \text { week } \\
\text { poultry }\end{array}$ & 1.8 & $\begin{array}{l}\text { Penicillium notatum, } P \text {. } \\
\text { oxalicum. } \\
\text { litter }\end{array}$ \\
4 week & 2.0 & $\begin{array}{l}\text { Penicillium notatum, } P . \\
\text { oxalicum, Aspergillus niger }\end{array}$ \\
litter & 3.4 & $\begin{array}{l}\text { Penicillium notatum, } P . \\
\text { oxalicum, Aspergillus niger, } \\
\text { A. flavus Mucor racemosus } \\
10 \text { week }\end{array}$ \\
litter & 3.7 & $\begin{array}{l}\text { Penicillium notatum, } P . \\
\text { Oxalicum, Apergillus niger, } \\
\text { A. Flavus, Mucor racemo- } \\
\text { sus, Trichoderma viride, } \\
\text { Crypyococcus neoformans } \\
\text { Saccharomyces cerevisae }\end{array}$ \\
\hline
\end{tabular}

$r=+0.972, P=0.006$

Source: Research data. 


\section{Discussion}

High fungal load was obtained in both settled dust and air of poultry confinements in this study. Similar high fungal load in poultry air has been reported in Germany (16). Fourteen different species of fungi were isolate. The health consequence of occupational exposure ranges from development of mycosis to mycotoxicosis.

The isolated fungi in this study are referred to as opportunistic fungi. They do not usually induce diseases, but do so when the body host defence is compromised (17). Among the important diseases associated with human exposure to organic dust is allergic broncho-pulmonary aspergillosis (ABPA), which occurs in patients with atopic asthma whose respiratory tracts are colonized with Aspergillus species. Clinical findings of ABPA include wheezing and generalized rales. The chest $\mathrm{x}$-ray may demonstrate recurrent migratory infilterates or evidence of central bronchiectasis and mucus plug impaction. Patients with chronic diseases may also demonstrate evidence of pulmonary fibrosis on chest $x$-rays $(17,18)$.

Mucor species and other Zygomycetes can invade the tissues of immuno-compromised individuals such as persons suffering from diabetes mellitus, severe burns, leukaemia, hymphoma, or other chronic diseases and immune-suppression. The fungi can invade and proliferate in the walls of blood vessels thereby producing thrombosis. This often occurs in the paranasal sinuses, the lungs and the gastrointestinal tract resulting in ischemic necrosis of surrounding tissue with massive infilteration of polymorphonuclear cells. Such conditions are referred to as mycormycosis when produced by Mucor species and zygomycosis when caused by Zygomycetes in general (17).

Exposure to fungi, particulary Stachybotrys atra (Stachybotrys chatarum) has been linked to cases of idiopathic pulmonary haemorhage (IPH) among infants (19). Between the year 1993 and 1998, a total of 138 cases of IPH were reported in the US (20). The incidence of pulmonary haemosiderosis in Sweden was found to be 2.4 per $10^{7}$ children per year (21) and a value of 1.1 per $10^{6}$ children per year in Japan (22). Stachybotris atra produces potent (trichothecene) that are toxic to both humans and animals. The symptoms produce by $S$. atra among exposed farm workers include nasal and tracheal bleeding, skin irritation and alteration in white blood cells (20).
Increase in fungal load with time in poultry litter and changes in species of fungi content was reported in this study. This variation in fungi species is an indication that there could be enrichment of the litter from time to time through feed, air and fomites.

Reasonable concentrations of aflatoxins, ochratoxins and fumonisins in poultry dust were reported in this study. This is an indication that the microfungi in poultry confinements produce potent toxins, which can cause various deleterious toxicological effects on the health of the birds as well as on the workers when dust is inhaled. Aflatoxins are commonly produced by Aspergillus flavus and A. parasiticus, as well as other Aspergillus species. Ochratoxins are produced by the Aspergillus ochraceus group and a number of species of Penicillium, especially $P$. viridicatum, while the fumonisins are produced by Fusarium moniliforme (7). Since many species of fungi are reported in this study, and such fungi are known to produce different types of toxins, it implies that the poultry dust consists of a variety of mycotoxins. Human exposure to poultry dust could therefore produce a variety of mycotoxicoses.

Aflatoxin was found to show a stronger positive correlation than fungal load with duration of dust deposition. This is because mycotoxins are retained in dead spores and mycelia of fungi. Inhalation of such old dust could hence expose such people to more health risk. This strong correlation of mycotoxin with duration of dust deposition could be exploited, as mycotoxin content of dust in an environment may be used to estimate its age; this may require further studies. Beside the mycotoxins content of dust, with potent toxicological effects, the $\beta$-D-glucan content of cell walls of fungi (whether dead or alive) are potent toxicological and inflammatory agents (23).

\section{References}

1. Sorenson WG. Fungal spores: hazards to health? Environ Health Perspect. 1999;108(3):469-72.

2. Tobin RS, Baranowski E, Gilman AP, Kuiper-Goodman T, Miller JD, Giddings M. Significance of fungi in indoor air: report of a working group. Canad J Public Health. 1987;78(2):S1-S32.

3. Haggblom P. De novo Synthesis of alternariol in conidia of Alternaria alternata. J Gen Microbiol. 1987; 133:3527-9. 
4. Palmgren MS, Lee LS. Separation of mycotoxin containing sources in grain dust and determination of their mycotoxins potential. Environ Health Perspect. 1986;66:105-8.

5. Wicklow DT, Shotwell OL. Intrafungal distribution of afflatoxin among conidia and selerotia of Aspergillus flavus and Aspergillus parasiticus. Canad J Microbiol. 1983;29(1):1-5.

6. Miller JD. Fungi as contaminants in indoor air. Atmos Environ.1992;26(12):2163-72. doi.org/10.1016/09601686(92):90404-9.

7. Jacobsen BJ, Bowen KL, Shelby RA, Diener UL. Mycotoxins and mycotoxicoses. Alabama cooperative Extension system Circular ANR - 767 Alabam A\& M and Aburu Universities; 1993. [acces em Jan. 10 2010]. Available at: http://www. access. edu/department/ grain/images/anr 76702.gis.

8. Varga J, Toth B. Novel strategies to control mycotoxin in feeds; a review. Acta Vet Hung. 2005;53(2):189-203.

9. Jand SK, Sharma NS, Paviter K. Mycoses and mycotoxicosis in poultry. A review. Indian J Anim Sci. 2005; 75(4):465-76.

10. Santurio JM. Mycotoxins and Mycotoxicosis in Poultry. Rev Bras Cienc Avícola. 2000;2(1):1-12.

11. Stoev SD, Stefanov M, Denev S, Radia B, Domijan AM, Peraica M. Experimental mycotoxicosis in chickens induced by ochratoxin A and penicillin acid and intervention with natural plant extract. Vet Res Communication. 2004;28(8):727-46.

12. Heedrick D, Brouwer R, Biersteker H, Boleij JSM. Relationship of airborne endotoxin and bacteria levels in pig farms with the lung function and respiratory symptoms of farmers. Inter Ach Environ Health. 1991;62(8):595-601.

13. Barnett HL, Hunter BB. Illustrated Genera of Imperfect Fungi. 3rd ed. Minneapolis: Burgess Publishing Company; 1972.
14. Domsch KH, Gams E. Fungi in agricultural soils. London: Longman; 1972.

15. Association of Analytical Chemists (AOAC). Official methods of analysis 14th ed. Washington D.C.: Association of Analytical Chemists; 1980.

16. Saleh M, Seedorf J, Hartung J. Inhalable and respirable dust, bacteria and endotoxins in the air of poultry houses. Dust Emission in Agriculture - dust Conference. 2007 [acces em Jan. 10 2010]. Available at: http: / /www.dustconf.org/CLIENT/DUSTCONF/ UPLOAD/812/HARTUNG_PDF.

17. Brooks GF, Carrol KC, Butel JS, Morse SA. Jawetz, Melnick \& Adelberg's Medical Micro-biology. New York: McGraw-Hill; 2007.

18. Brown GP, Hunnighake EW. Pulmomary diseases. In: Stirel DP, Stobo JD, Wells JV. Editors. Basic and clinical immunology appleten of lange. East Norwalk: Connedicut; 1987.

19. Flappan SM, Portnoy J, Jones P, Barnes C. Infant pulmonary hemorrhage in a suburban home with water damage and mold (Stachybotrys atra). Environ Health Perspect. 1999;107:(11):927-30.

20. Dearborn DG, Yike I, Sorenson WG, Miller MJ, Etzel RA. Overview of investigations into pulmonary hemorrhage among infants in Cleveland, Ohio. Environ Health Perspect. 1999;107(Suppl 3):495-9.

21. Kjellman B, Elinder G, Garwicz S, Svan H. Idiopathic pulmonary haemosiderosis in Swedish children. Acta Paediatr Scand. 1984;73(5):584-8. doi: 10.1111/j.1651-2227.1984.tb09978.x.

22. Ohga S, Takahashi K, Miyazaki S, Kato H, Ueda K. Idiopathic pulmonary haemosiderosis in Japan: 39 possible cases from a survey questionnaire. Eur J Pediatr. 1995;154(12):994-5.

23. Rylander R. Microbial cell wall constituents in indoor air and their relation to diseases. Indoor Air 1998; 4(Suppl.):59-65. 